\title{
ANALISIS HUBUNGAN TINGKAT PEMAHAMAN MATERI PERKULIAHAN PENGANTAR ILMU LINGKUNGAN DENGAN MENGGUNAKAN GOOGLE CLASSRROM TERHADAP HASIL BELAJAR MAHASISWA
}

\author{
Vina N. Van Harling \\ Politeknik Saint Paul Sorong \\ email: vina.nathalia@poltekstpaul.ac.id
}

\begin{abstract}
Google classroom is a service developed by Google, in this case, Google for Education, which aims to simplify the assignments of teachers. This research was conducted to analyze the relationship between the level of understanding of environmental science introductory course material using Google classroom on student learning outcomes. This research is a correlational study, the research data were collected using a questionnaire collection method and documentation method. The research was conducted at Saint Paul Polytechnic in Sorong, an Electrical Engineering study program, the sample used was 9 people from the total population. The test results obtained by $r$ count from the results of testing the relationship between the level of understanding of introductory environmental science subject matter using Google classroom to student learning outcomes of 0.158 which when compared to the test results with the value of $r$ table, then the value of $r$ count $<r$ table $(0.158<0.666)$. While the comparison of significance obtained a significance value $>0.05(0.686>0.05)$, which means that there is no relationship between the two variables tested.
\end{abstract}

Keyword: Level Of Understanding, Google classroom, Learning Outcomes

\begin{abstract}
Abstrak : Google classroom merupakan layanan yang dikembangkan oleh google dalam hal ini adalah Google for Education yang memiliki tujuan menyederhanakan tugas para pengajar. Penelitian ini dilakukan dengan tujuan untuk menganalisis hubungan tingkat pemahaman materi perkuliahan pengantar ilmu lingkungan dengan menggunakan Google classroom terhadap hasil belajar mahasiswa. Penelitian ini merupakan penelitian korelasional, data penelitian dikumpulkan dengan menggunakan metode pengumpulan kuesioner dan metode dokumentasi. Penelitian dilakukan di Politeknik Saint Paul Sorong, program studi Teknik Elektro, sampel yang digunakan 9 orang dari total populasi. Hasil pengujian diperoleh $r$ hitung dari hasil pengujian hubungan antara tingkat pemahaman materi perkuliahan pengantar ilmu lingkungan dengan menggunakan Google classroom terhadap hasil belajar mahasiswa sebesar 0,158 yang bila dibandingkan hasil pengujian dengan nilai $r$ table, maka nilai $r$ hitung < $\mathrm{r}$ table $(0,158<0,666)$. Sementara perbandingan signifikansi diperoleh nilai signifikansi $>0,05(0,686>0,05)$ yang berarti bahwa tidak terdapat hubungan antara kedua variable yang diujikan.
\end{abstract}

Kata Kunci : Tingkat Pemahaman, Google classroom, Hasil Belajar

\section{PENDAHULUAN}

Sejak hadirnya pandemic Covid-19 di Indonesia di awal tahun 2020, seluruh proses belajar mengajar yang dilakukan secara langsung bertatap muka dengan siswa maupun mahasiswa berubah menjadi belajar dari rumah atau lebih dikenal 
dengan belajar online atau daring. Proses belajar seperti ini ternyata masih tetap berlangsung hingga tahun 2021 dan belum dipastikan kapan proses pembelajaran akan kembali seperti sebelumnya. Pembelajaran online atau pembelajaran daring adalah pembelajaran yang memanfaatkan teknologi dalam kegiatan proses belajar mengajar, yang dapat dikatakan merupakan pergantian dari cara konvensional menjadi cara modern (Handarini 2020).

Dalam pelaksanaannya, pembelajaran online memerlukan banyak fasilitas yang dapat menunjang proses belajar seperti laptop, handphone, komputer dan yang paling diperlukan adalah fasilitas jaringan internet. Dalam penelitiannya Handarini (2020) menuliskan bahwa penggunaan internet dan multimedia mampu mengubah cara menyampaikan ilmu pengetahuan yang ada dan penggunaan internet dapat digunakan sebagai salah satu alternatif pembelajaran yang dilaksanakan dalam kelas. Untuk itulah saat ini proses pembelajaran yang dilakukan adalah proses pembelajaran daring (dalam jaringan) atau lebih dikenal dengan pembelajaran online (Van Harling 2020) .

Di Indonesia proses pembelajaran online dibantu oleh beberapa aplikasi seperti Zoom, Edmodo, dan Web blog. Bahkan saat pertengahan tahun 2020 untuk mengurangi permasalahan yang ada pemerintah memberikan tambahan 12 aplikasi belajar yang dapat digunakan oleh pelajar dan mahasiswa untuk belajar dari rumah seperti: Google for education, Microsoft office, Cisco webex, Quipper school, Zenius, Ruang guru, Rumah belajar, Meja kita, Icando, Indonesiax, Kelas pintar, dan Sekolahmu.

Politeknik Saint Paul Sorong merupakan salah satu dari banyaknya Perguruan Tinggi di Indonesia yang turut memanfaatkan aplikasi belajar yang disediakan oleh pemerintah. Aplikasi yang dipilih untuk digunakan selama proses pembelajaran adalah Google classroom. Dimana materi perkuliahan yang akan diberikan oleh dosen kepada mahasiswa selama 1 semester akan dimasukkan ke dalam Google classroom. Selain materi perkuliahan dosen juga dapat memberikan modul, video perkuliahan, tugas, ujian tengah semester, ujian akhir semester, hingga informasi lain yang berhubungan dengan perkuliahan dilakukan di Google classroom.

Google classroom merupakan layanan yang dikembangkan oleh google dalam hal ini adalah Google for Education yang memiliki tujuan menyederhanakan 
tugas para pengajar untuk membuat, mendistribusikan serta menilai tugas - tugas dan ujian secara langsung tanpa harus menggunakan kertas. Dalam pelaksanaannya penggunaan Google classroom dapat dibuat berdasarkan kelas perkuliahan, sehingga mahasiswa akan ditambahkan sesuai dengan kontrak kuliah setiap mahasiswa selama semester berjalan. Pendistribusian materi perkuliahan, video perkuliahan, modul, tugas serta ujian dapat langsung ditambahkan ke dalam Google classroom dan akan tersimpan di dalam google drive setiap pengajar. Selain itu setiap pengajar dapat langsung berkomunikasi dengan mahasiswa melalui email (Gmail) atau langsung di dalam Google classroom.

Salah satu mata kuliah yang di ajarkan pada semester ganjil Tahun Ajaran 2020/2021 adalah mata kuliah pengantar ilmu lingkungan. Mata kuliah ini merupakan ilmu yang mengintegrasikan berbagai ilmu yang mempelajari hubungan antara makhluk hidup dengan makhluk hidup lainnya (termasuk manusia) serta lingkungannya. Selain itu juga dipelajari dasar dari ilmu lingkungan yang lebih dikenal dengan ilmu ekologi, sehingga sering dikatakan bahwa ilmu lingkungan merupakan titik pertemuan antara ilmu murni dan ilmu terapan (Setiadi 2015).

Selama proses perkuliahan mata kuliah ini berisikan materi yang perlu dikaji dengan baik dan jelas agar mahasiswa memperoleh pemahaman yang mendalam tentang lingkungan. Harapannya output yang dihasilkan dari perkuliahan ini adalah mahasiswa dapat mengelola lingkungan hidup secara lebih baik. Dalam artian mahasiswa dapat meminimalkan kerusakan - kerusakan lingkungan serta dapat mengoptimalkan manfaat yang dimiliki oleh lingkungan ke depannya. Harapan ini kemudian akan menjadi suatu tantangan terbesar bagi dosen yang mengampu mata kuliah ini semenjak hadirnya Covid-19, yang menyebabkan proses perkuliahan berpindah dari kelas yang nyata menjadi kelas kelas online atau daring.

Beberapa penelitian yang menunjukkan efektifitas belajar penggunaan aplikasi yang disediakan seperti penelitian yang dilakukan oleh Khusniyah (2019) tentang Efektivitas Pembelajaran Berbasis Daring: Sebuah Bukti Pada Pembelajaran Bahasa Inggris. Dalam penelitian ini pembelajaran daring memanfaatkan penggunaan web blog. Hasil penelitian menunjukkan bahwa bahwa ada perbedaan kemampuan pemahaman mahasiswa terhadap teks berbahasa Inggris antara sebelum dan sesudah penggunaan web blog. Dalam hal ini, pembelajaran 
daring berbantuan web blog tersebut memberikan pengaruh positif terhadap peningkatan kemampuan membaca bahasa Inggris mahasiswa.

Di tahun yang berbeda Daheri (2020) mengenai Efektifitas whatsapp sebagai media belajar daring. Hasil penelitian menunjukkan bahwa pembelajaran daring melalui Whatsapp pada sekolah dasar cendrung tidak efektif. Sementara ditahun yang sama Hikmat (2020) melakukan penelitian dengan tujuan menganalisis efektivitas pembelajaran daring di masa Pandemi Covid-19. Pembelajaran daring dalam penelitian ini adalah menggunakan aplikasi Zoom untuk tatap muka dan Whatsapp untuk memberikan materi kuliah serta penugasan untuk media belajar daring. Hasil pengujiannya didapatkan bahwa belajar secara daring dengan Zoom dan Whatsapp hanya efektif bagi matakuliah teori dan praktikum, sedangkan pada matakuliah praktik dan matakuliah lapangan perkuliahan secara online kurang efektif.

Penelitian lain yang melibatkan penggunaan aplikasi lainnya adalah penelitian dari Suhada (2020) tentang Pembelajaran daring berbasis Google classroom mahasiswa pendidikan biologi pada masa wabah Covid-19. Dimana diperoleh hasil penelitian bahwa penggunaan aplikasi Google classroom dalam pembelajaran daring pada masa wabah covid-19 sudah cukup baik dan efektif, hanya saja akan lebih baik jika dipadukan dengan platform online lainnya.

Berdasarkan penelitian - penelitian yang ada sebelumnya menunjukkan bahwa penggunaan beberapa aplikasi belajar daring dinilai kurang efektif. Penggunaan aplikasi Google classroom dinilai akan efektif bila diikuti dengan penggunaan aplikasi yang lain seperti zoom dan google meet. Namun hasil penelitian belum menunjukkan hubungan kefektifan penggunaan aplikasi belajar ini dengan hasil belajar. Untuk itu, peneliti merasa perlu untuk mengkaji bagaimana hubungan tingkat pemahaman mahasiswa selama proses perkuliahan pengantar ilmu lingkungan yang dilakukan secara online atau daring dengan menggunakan salah satu aplikasi yaitu Google classroom terhadap hasil belajar mahasiswa. Aplikasi daring yang digunakan dalam penelitan ini menyesuaikan penggunaan aplikasi yang paling sering digunakan di Politeknik Saint Paul selama perkuliahan daring. 


\section{METODE}

Penelitian ini merupakan penelitian korelasional yang akan digunakan untuk melihat hubungan antara tingkat pemahaman materi perkuliahan pengantar ilmu lingkungan dengan menggunakan Google classroom terhadap hasil belajar mahasiswa. Data penelitian dikumpulkan dengan menggunakan metode pengumpulan kuesioner yang diperoleh dengan menggunakan kuesioner yang diisi langsung oleh mahasiswa dengan menggunakan google formulir. Kuesioner yang digunakan sebelumnya dilakukan pengujian validitas dan reliabilitas instrument. Sementara data hasil belajar mahasiswa untuk mata kuliah pengantar ilmu lingkungan diperoleh dengan menggunakan metode dokumentasi. (Van Harling 2019) Penelitian dilakukan di Politeknik Saint Paul Sorong, program studi Teknik Elektro untuk mahasiswa yang mengambil mata kuliah pengantar ilmu lingkungan. Populasi yang digunakan dalam penelitian ini berjumlah 9 orang sehingga dianggap sebagai sampel penelitian.

Penelitian ini menggunakan metode deskriptif kuantitatif untuk menganalisis data dengan cara mendeskripsikan atau menggambarkan data yang telah terkumpul sebagaimana adanya tanpa bermaksud membuat kesimpulan yang berlaku untuk umum. (Sugiyono 2016) Data yang dianalisis meliputi nilai rata - rata, median, modus, simpangan baku dan varian. Sementara untuk mencari hubungan tingkat pemahaman materi perkuliahan pengantar ilmu lingkungan dengan menggunakan Google classroom terhadap hasil belajar mahasiswa menggunakan analisis korelasi Person. (Santoso 2010) Data penelitian yang diperoleh kemudian di analisis statistik deskriptif dan korelasi dengan menggunakan IBM SPSS Statistics 25 (Priyantno 2016).

\section{HASIL DAN PEMBAHASAN}

\section{Hasil}

Pengujian reliabilitas dan validitas dilakukan dalam penelitian ini untuk instrumen pengukuran tingkat pemahaman materi perkuliahan pengantar ilmu lingkungan dengan menggunakan Google classroom. Instrumen dinyatakan reliabel apabila nilai Cronbach's Alpha > nilai r tabel 0,666. Sementara untuk pengujian validitas data dinyatakan valid apabila nilai $r$ hitung $>r$ table. 
Tabel 1. Hasil Pengujian Reliabilitas

\begin{tabular}{rr}
\hline \multicolumn{2}{c}{ Reliability Statictics } \\
\hline Cronbach's Alpha & N of Items \\
\hline $\mathbf{. 9 5 1}$ & 8 \\
\hline
\end{tabular}

Tabel 2. Hasil Pengujian Validitas

\begin{tabular}{crrrr}
$\begin{array}{c}\text { No. } \\
\text { Pernyataan }\end{array}$ & $\begin{array}{c}\text { Corrected Item } \\
- \text { Total } \\
\text { Correlation }\end{array}$ & $\begin{array}{c}\text { Cronbach's } \\
\text { Alpha if Item } \\
\text { Deleted }\end{array}$ & $\begin{array}{c}\text { R- } \\
\text { Tabel }\end{array}$ & Keterangan \\
\hline $\mathbf{1}$ & .866 & .941 & 0,666 & Valid \\
\hline $\mathbf{2}$ & .897 & .939 & 0,666 & Valid \\
\hline $\mathbf{3}$ & .725 & .950 & 0,666 & Valid \\
\hline $\mathbf{4}$ & .793 & .950 & 0,666 & Valid \\
\hline $\mathbf{5}$ & .852 & .943 & 0,666 & Valid \\
\hline $\mathbf{6}$ & .793 & .946 & 0,666 & Valid \\
\hline $\mathbf{7}$ & .917 & .939 & 0,666 & Valid \\
\hline $\mathbf{8}$ & .839 & .947 & 0,666 & Valid \\
\hline
\end{tabular}

Pengujian normalitas data merupakan salah satu prasyarat pokok yang harus digunakan dalam analisis parametrik, karena data yang digunakan harus berdistribusi normal. Data dinyatakan berdistribusi normal jika nilai signifikansi lebih besar dari 0,05 . Hasil pengujian normalitas instrument penelitian di sajikan dalam table 3 .

Tabel 3. Normalitas data Hubungan Tingkat Pemahaman Materi Perkuliahan Pengantar Ilmu Lingkungan dengan Menggunakan Google classroom Terhadap Hasil Belajar Mahasiswa

\begin{tabular}{|c|c|c|c|c|c|c|}
\hline \multicolumn{7}{|c|}{ Tests of Normality } \\
\hline & \multicolumn{3}{|c|}{ Kolmogorov-Smirnov $^{\mathrm{a}}$} & \multicolumn{3}{|c|}{ Shapiro-Wilk } \\
\hline & Statistic & $\mathrm{df}$ & Sig. & Statistic & $\mathrm{df}$ & Sig. \\
\hline $\begin{array}{l}\text { Pemahaman } \\
\text { materi }\end{array}$ & .164 & 9 & .200 & .938 & 9 & .558 \\
\hline $\begin{array}{l}\text { Hasil Belajar } \\
\text { Mahasiswa }\end{array}$ & .176 & 9 & .200 & .947 & 9 & .662 \\
\hline
\end{tabular}
hasil pengujian normalitas untuk pemahaman materi dihasilkan nilai signifikansi > 0,05 yaitu $0,558>0,05$. Sehingga dapat dikatakan bahwa distribusi sampel yang digunakan adalah normal. Untuk hasil pengujian normalitas dari pengukuran hasil belajar mahasiswa besarnya signifikansi yang dihasilkan adalah 0,662 yang berarti bahwa nilai signifikansi yang dihasilkan > 0,05 sehingga dikatakan bahwa sampel berdistribusi normal. 
Analisis statistik deskriptif dari sebaran kuesioner Instrumen Analisis Hubungan Tingkat Pemahaman Materi Perkuliahan Pengantar Ilmu Lingkungan dengan Menggunakan Google classroom Terhadap Hasil Belajar Mahasiswa ditampilkan dalam tabel 4

Tabel 4. Analisis Deskriptif Tingkat Pemahaman Mahasiswa dan Hasil Belajar

\begin{tabular}{|c|c|c|c|c|c|c|c|c|}
\hline \multicolumn{9}{|c|}{ Descriptive Statistics } \\
\hline & $\mathrm{N}$ & Rang & Minim & Maximu & & & Std. & Varian \\
\hline & $\begin{array}{c}\text { Statis } \\
\text { tic }\end{array}$ & $\begin{array}{c}\text { Statis } \\
\text { tic }\end{array}$ & $\begin{array}{c}\text { Statisti } \\
\text { c }\end{array}$ & Statistic & $\begin{array}{c}\text { Statis } \\
\text { tic }\end{array}$ & $\begin{array}{l}\text { Std. } \\
\text { Error }\end{array}$ & Statistic & $\begin{array}{c}\text { Statisti } \\
\text { c }\end{array}$ \\
\hline Pemahaman & 9 & 16 & 16 & 32 & 25.8 & 1.783 & 5.349 & 28.611 \\
\hline Mahasiswa & & & & & 9 & & & \\
\hline Belajar & 9 & 16 & 67 & 83 & 75.8 & 1.637 & 4.910 & 24.111 \\
\hline Mahasiswa & & & & & 9 & & & \\
\hline Valid N (listwise) & 9 & & & & & & & \\
\hline
\end{tabular}

Berdasarkan hasil analisis data di atas, diperoleh bahwa untuk data tingkat pemahaman mahasiswa dengan jumlah data (sampel) 9 orang, memiliki nilai maksimum 36 dan minimum 20 sehingga range yang diperoleh dari data tingkat pemahaman mahasiswa adalah 16. Nilai mean yang diperoleh sebesar 29,11 dengan besarnya standar error 1,933. Sementara hasil pengujian menunjukkan standar deviasi dan varian berturut - turut 5,798 dan 33,611. Lebih lanjut dari table 4 menunjukkan bahwa hasil analisis deskriptif untuk hasil belajar diperoleh besarnya nilai maksimum dan minimum berturut - turut sebesar 83 dan 67 sehingga range yang diperoleh adalah 16. Besarnya nilai mean yang diperoleh adalah 683 dengan standar error 1,637. Hasil pengujian juga menunjukkan bahwa standar deviasi yang diperoleh adalah 4,910 dan nilai varians yang dihasilkan sebesar 24,111.

Analisis korelasi bertujuan mengetahui apakah diantara kedua variable terdapat hubungan antara satu dengan yang lain atau tidak. Selain itu juga analisis korelasi digunakan untuk melihat arah hubungan dan seberapa besar hubungan yang terjadi antara kedua variable. Dua variable dapat dikatakan tidak berhubungan sama sekali bila nilai $r=0$, dan berhubungan sempurna atau sangat kuat bila nilai $r$ $=1$ atau diantara kedua angka tersebut. (Santoso. 2010) Hasil pengujian korelasi di sajikan dalam table 5 .

Tabel 5. Korelasi Tingkat Pemahaman Materi Perkuliahan Pengantar Ilmu Lingkungan

Dengan Menggunakan Google classroom Terhadap Hasil Belajar Mahasiswa

\begin{tabular}{|c|c|c|c|}
\hline \multicolumn{4}{|c|}{ Correlations } \\
\hline & & Pemahaman Mahasiswa & Hasil Belajar \\
\hline \multirow{3}{*}{$\begin{array}{l}\text { Pemahaman } \\
\text { Mahasiswa }\end{array}$} & Pearson Correlation & 1 & -.158 \\
\hline & Sig. (2-tailed) & & .686 \\
\hline & $\mathrm{N}$ & 9 & 9 \\
\hline \multirow{3}{*}{$\begin{array}{l}\text { Hasil Belajar } \\
\text { Mahasiswa }\end{array}$} & Pearson Correlation & -.158 & 1 \\
\hline & Sig. (2-tailed) & .686 & \\
\hline & $\mathrm{N}$ & 9 & 9 \\
\hline
\end{tabular}


Berdasarkan hasil uji di atas terlihat bahwa besarnya nilai $r$ hitung 0,158 . Besarnya nilai $r$ table diperoleh dengan melihat $r$ table dengan taraf kesalahan sebesar 5\% atau tingkat kepercayaan $95 \%$ dan nilai $\mathrm{N}=9$ maka diperoleh nilai $\mathrm{r}$ table 0,666. Bila dibandingkan hasil pengujian dengan nilai $r$ table maka nilai $r$ hitung $<\mathrm{r}$ table $(0,158<0,666)$ yang berarti bahwa tidak terdapat hubungan antara kedua variable penelitian. Sementara tingkat signifikansi hubungan antara kedua variable diperoleh perbandingan nilai signifikansi $>0,05(0,686>0,05)$, sehingga dapat dikatakan bahwa tidak terdapat hubungan antara kedua variable yang diujikan.

\section{Pembahasan}

Pengujian korelasi dilakukan untuk melihat hubungan yang terjadi antara kedua variable. Hasil penelitian ditemukan bahwa kedua variebel yang diujikan tidak berkorelasi yang signifikan antara satu dengan yang lain. Hal ini berarti tidak terdapat hubungan yang signifikan antara tingkat pemahaman materi perkuliahan pengantar ilmu lingkungan dengan menggunakan Google classroom dengan hasil belajar mahasiswa. Apabila hasil penelitian ini dibandingkan dengan hasil penelitian lainnya, hasil penelitian ini sangat berbeda dengan hasil penelitian yang telah dilakukan sebelumnya. Rachmat (2020) penelitiannya tentang Analisis Efektifitas Pembelajaran Daring (Online) Untuk Siswa SMK Negeri 8 Kota Tangerang Pada Saat Pandemi Covid 19 memperoleh hasil pembelajaran daring untuk siswa SMK Negeri 8 Kota Tangerang kurang efektif dan berbanding lurus dengan pemahanan siswa yaitu kurang paham dengan pembelajaran yang diberikan guru melalui pembelajaran daring.

Hasil penelitian yang diperoleh juga berbeda dengan hasil penelitian dari Ramadhan (2020) mengenai Efektifitas pembelajaran sejarah kebudayaan Islam melalui Google classroom ditinjau dari hasil belajar siswa. Hasil penelitian menunjukkan bahwa pembelajaran jarak jauh dengan menggunakan Google classroom apabila ditinjau dari hasil belajar siswa cukup efektif menurut tafsiran $\mathrm{N}$-Gain dengan perolehan persentase sebesar $58.3 \%$. Hasil pengujian menunjukkan tidak adanya hubungan yang diperoleh dari kedua variable yang diujikan dapat disebabkan adanya aplikasi pembelajaran lain yang dapat digunakan oleh mahasiswa diluar penggunaan Google classroom selama proses perkuliahan yang pada akhirnya dapat membantu mahasiswa untuk lebih memahami materi yang diberikan melalui Google classroom. Hal ini sejalan dengan hasil penelitian dari Widiyono (2020) yang menyatakan bahwa selain menggunakan Google classroom mahasiswa menggunakan beberapa aplikasi pembelajaran secara umum seperti whatsaap grup, telegram group, dan youtube. Sehingga dapat dikatakan bahwa tingkat pemahaman mahasiswa terhadap mata kuliah pengantar ilmu lingkungan tidak berasal dari Google classroom saja tetapi dari berbagai aplikasi yang digunakan oleh mahasiswa untuk memperoleh informasi mengenai materi kuliah yang diberikan. 
Baiknya hasil belajar mahasiswa dikatakan tidak memiliki hubungan dengan tingkat pemahaman materi perkuliahan dengan menggunakan Google classroom karena banyak factor yang mempengaruhi pencapaian hasil belajar yang baik oleh mahasiswa. Dalam penelitiannya Riyani (2012) menyatakan bahwa terdapat 4 faktor yang mempengaruhi yaitu Faktor 1 terdiri dari Proses Belajar Mengajar, Metode, Sumber dan Mahasiswa, Faktor 2 terdiri atas Bahan Ajar, Alat, Motivasi dan Evaluasi, Faktor 3 terdiri atas Interaksi mahasiswa dengan materi, Lingkungan dan Kesehatan sedangkan Faktor 4 terdiri atas Tujuan dan Bakat. Selain itu persepsi mahasiswa juga memberikan kontribusi yang besar terhadap hasil belajar mahasiswa karena persepsi yang baik akan membantu mahasiswa untuk menikmati proses perkuliahan, mahasiswa tidak akan merasa tertekan ataupun keberatan dalam melakukan segala aktifitas perkuliahan sehingga akan berdampak pada hasil belajar (Nugraha 2015).

\section{SIMPULAN}

Dari penelitian dan pembahasan dapat ditarik bahwa tidak terdapat hubungan yang signifikan antara tingkat pemahaman materi perkuliahan pengantar ilmu lingkungan dengan menggunakan Google classroom dengan hasil belajar mahasiswa.

\section{DAFTAR RUJUKAN}

Daheri, M., Juliana, J., Deriwanto, D., \& Amda, A. D. (2020). Efektifitas whatsapp sebagai media belajar daring. Jurnal Basicedu, 4(4), 775-783.

Handarini, O. I., \& Wulandari, S. S. (2020). Pembelajaran Daring Sebagai Upaya Study From Home (SFH) Selama Pandemi Covid 19. Jurnal Pendidikan Administrasi Perkantoran (JPAP), 8(3), 496-503.

Hikmat, H., Hermawan, E., Aldim, A., \& Irwandi, I. (2020). Efektivitas pembelajaran daring selama masa pandemi Covid-19: Sebuah survey online. LP2M.

Khusniyah, N. L., \& Hakim, L. (2019). Efektivitas Pembelajaran Berbasis Daring: Sebuah Bukti Pada Pembelajaran Bahasa Inggris. Jurnal Tatsqif, 17(1), 1933.

Nugraha, U. (2015). Hubungan Persepsi, Sikap Dan Motivasi Belajar Terhadap Hasil Belajar Pada Mahasiswa Pendidikan Olahraga Dan Kesehatan Universitas Jambi. Cerdas Sifa Pendidikan, 4(1).

Priyatno, D. (2016). SPSS handbook. Yogyakarta: Mediakom.

Rachmat, A., \& Krisnadi, I. (2020). Analisis Efektifitas Pembelajaran Daring (Online) Untuk Siswa SMK Negeri 8 Kota Tangerang Pada Saat Pandemi Covid 19. Magister Teknik Elektro Universitas Mercu Buana, 1-7.

Ramadhan, O. M., \& Tarsono, T. (2020). Efektifitas pembelajaran sejarah kebudayaan Islam melalui Google classroom ditinjau dari hasil belajar siswa. JINoP (Jurnal Inovasi Pembelajaran), 6(2), 204-214.

Riyani, Y. (2015). Faktor-faktor yang mempengaruhi prestasi belajar mahasiswa (studi pada mahasiswa Jurusan Akuntansi Politeknik Negeri Pontianak). 
Santoso SInggih. (2010) Statistik Parametrik. PT. Alex Media Komputindo; Jakarta Setiadi, Dede. (2015). Pengantar Ilmu Lingkungan. IPB Press. Bogor

Suhada, I., Kurniati, T., Pramadi, A., \& Listiawati, M. (2020). Pembelajaran daring berbasis Google classroom mahasiswa pendidikan biologi pada masa wabah Covid-19. Digital Library UIN Sunan Gunung Djati, 1-10.

Van Harling, V. N., \& Tobi, M. D. (2019). HUBUNGAN ANTARA PEMANFAATAN FASILITAS LABORATORIUM KIMIA DAN KEDISIPLINAN BELAJAR KIMIA DENGAN PRESTASI BELAJAR KIMIA SISWA KELAS XII IPA SMA NEGERI 1 SORONG. SOSCIED, 2(2), 64-75.

Van Harling, V. N. (2020). ANALISIS HUBUNGAN KEDISIPLINAN BELAJAR DARI RUMAH (BDR) DENGAN PRESTASI BELAJAR KIMIA SISWA SELAMA MASA PANDEMI. SOSCIED, 3(2), 80-85.

Widiyono, A. (2020). Efektifitas perkuliahan daring (online) pada mahasiswa pgsd di saat pandemi covid 19. Jurnal Pendidikan, 8(2), 169-177. 